\title{
Intraoral De-Epithelialized Gingival Graft in the Treatment of Multiple Adjacent Gingival Recessions: Case Report with a 1-Year Follow-Up
}

\author{
Hikmat Bakhishov ${ }^{1 *}$ and Burcu Özdemir ${ }^{2}$ \\ ${ }^{1}$ HB Private Dental Clinic, Turkey \\ ${ }^{2}$ AssociateProfessor, Department of Periodontology, Dentistry Faculty, Gazi University, Turkey
}

Submission: May 17, 2021; Published: June 02, 2021

*Corresponding author: Hikmat Bakhishov, HB Private Dental Clinic, Istanbul, Turkey

Abstract

Background: This article depicts a clinical case with 1 year follow-up in which de-epithelialized gingival graft (DGG) was used with the tunnel technique to treat multiple gingival recessions (GRs), and describes a technique used to intraoral de-epithelialization with diamond burr.

Methods: A 45-year-old male patient was referred for evaluation and treatment of anterior maxillary multiple GRs. DGG with the tunnel technique was proposed to coverage of Cairo Recession Type I GRs on teeth \#21 through \#22 and an on tooth\#23. Tunnel bed area had been prepared with microblades and tunnel knives. Donor are measured and de-epithelialized with diamond burs intraorally. After DGG harvested split cross-sectionally. The DGG was placed through the tunnel bed with auxillary sutures and sutured with vertical double-crossed technique.

Results: Ten days after the surgical procedure, the tissue region was homogeneous where there is not uncovered DGG part, and clinically increased tissue thickness was observed. After 1 years of follow-up, the mean coverage $92.2 \%$. Besides, increasing of tissue thickness was observed.

Conclusion: Intraoral DGG using with the tunnel technique successfully for treatment of multiple GRs with an increase of the soft tissue thickness and gain aesthetic outcomes.

Keywords: Case report; Gingival recession; De-epithelized gingival graft; Root coverage; Tunnel technique

Abbreviations: DGG: De-epithelialized Gingival Graft; GR: Gingival Recessions; CAF: Coronally Advanced Flap; SAF: Semilunar Advanced Flap; FGG: Free Gingival Graft; EMD: Enamel Matrix Protein Derivatives; ADM: Acellular Dermal Matrix Allograft; GTR: Guided Tissue Regeneration; CTG: Connective Tissue Grafts; Plaque Index; GI: Gingival Index

\section{Introduction}

Gingival recessions, is defined as shift of gingival margin to apical aspect with exposure of root surface, is a pivotal problem that, affects the majority of adults in populations [1]. GRs may result in tooth sensitivity, cause root surface caries, aesthetic deficiency and clinical attachment loss. Complete root coverage and aesthetic integrity are aimed to the treatment of localized and multiple GRs using different methods [2]. GRs can be determined as single and multiple by the number of affected teeth. GRs have several ethiologic factors have been considered primary or predisposing factors that can be grouped in: anatomical factors (e.g., lack of attached gingival, muscular insertions, tooth misalignment, inadequate thickness of the alveolar bone plate and root prominences; (e.g., periodontitis or viral infections); iatrogenic factors (e.g., improper restorations) and mechanical trauma (e.g., toothbrushing trauma or lip piercing) [3].

Several methods of GRs treatment exist: Pedicle Grafts ( Pedicle Flaps), Laterally Sliding Flap [4], Double Papilla Flap Technique [5], Oblique Rotated Flap [6]. Advanced Flap Procedures: Coronally Advanced Flap (CAF) [7], Semilunar Advanced Flap [8]. Free Gingival Graft ( FGG ) ( Bjorn 1963): Single stage ( FGG ) [9], Double stage ( FGG + CAF) [7]. Subepithelial Connective Tissue Graft [10], Subepithelial Connective Tissue Graft + Rotation Flap [11], Subepithelial Connective Tissue Graft + Pouch Technique [12], Tunnel Technique [13]. Biomimetic Approach: Enamel 
Matrix Protein Derivatives ( EMD) [14], Acellular Dermal Matrix Allograft (ADM) [15], Guided Tissue Regeneration ( GTR) [16].

Zucchelli et al. [17] performed DGG harvesting extraorally to treatment of GRs using coronally advanced flap (CAF) technique. Using DGG has minimized chair time during operation was recorded [17]. Implementation DGG with tunnel technique in the treatment of gingival recessions was successfull [18], many alternative products as connective tissue grafts (CTG), collagen matrix [19], acelular dermal allo- and xenografts [20] have been studied. In spite of many articles, few articles have discussed using DGG for multiple recessions, especially when associated with the tunnel technique $[18,21]$. The subepithelial connective tissue graft is a predictable and versatile technique in treatment of gingival recessions $[10,22]$. Differences in hard palate anatomy $[23,24]$ and insufficient fibromucosal thickness $(\leq 2.5 \mathrm{~mm})[25]$ may complicate harvesting CTG $[2,26]$. In the presence of multiple GRs, graft length and appropriate graft selection should always be considered for the patient's satisfactory aesthetic results.

\section{Case Report}

45 old year male patient was referred to the HB Private Dental Clinic in July 2019 for evaluation and treatment of anterior maxillar GRs (Figure 1). His essential complaint was severe dentin sensitivity. He was non-smoking, general healthy and well educated about oral hygiene procedure. Clinical evaluation indicated plaque index [27] (PI) of $<15 \%$ and gingival index (GI) [28] of $13 \%$, probing depth was $\leq 3 \mathrm{~mm}$. Following local anesthesia, scaling and root planning of the exposed root surfaces were performed with Gracey curettes. Afterwards, interdental spaces were splinted with flowable composite resin for hanging sutures, without previous acid etching. Sulcular incisions were performed from \#11 to \#24 through the buccal aspect with microblades (Figure 2). Tunnel bed was prepared with specific tunnel instruments (Hu-Friedy, USA) preserving the integrity of the gingivo-papillae complex carefully (Figure 3). The second step was to harvest DGG from the premolar palatal fibro-mucosa: First, determined graft region was de-epithelialized (Figure 4) with diamond burs (Figure 5). under saline irrigation Afterwards DGG was harvested by $15 \mathrm{C}$ scalpel blades, approximately $1.5 \mathrm{~mm}$ thickness (Figure 6). Donor palatinal site was sutured with horizontal cross sutures (5-0 monofilament propilen, Dogsan, Trabzon, Turkey). Harvested DGG was positioned and placed through auxiliary 5-0 monofilament sutures (Figure 7). Positioned DGG and elevated papillae complex were sutured with vertical double-crossed sutures (Figure 8). Patient was advised to avoid trauma and irritants. An analgesic (flurbiprofen $100 \mathrm{mg}$, two times a day for 3 days) and mouthrinse with $0.12 \%$ chlorhexidine digluconate (twice a day for 10 days) were prescribed after operation.

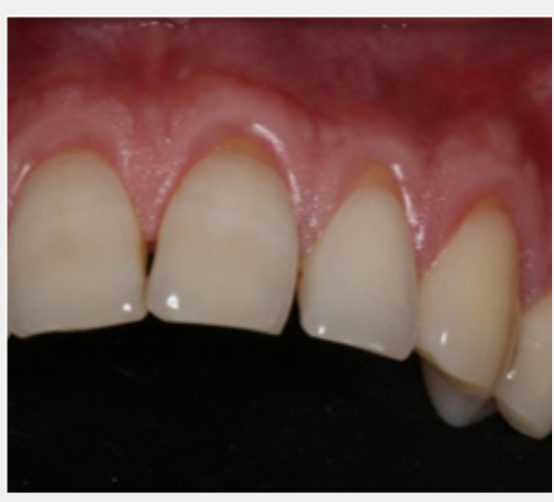

Figure 1: Baseline view of multipleGRs.

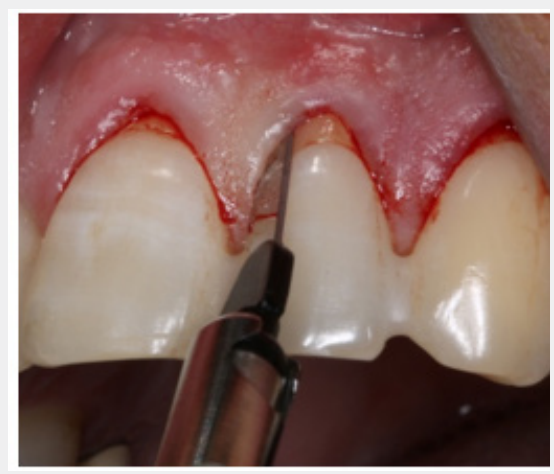

Figure 2: Microblade was used to perform sulcular incision. 


\section{Advances in Dentistry \& Oral Health}

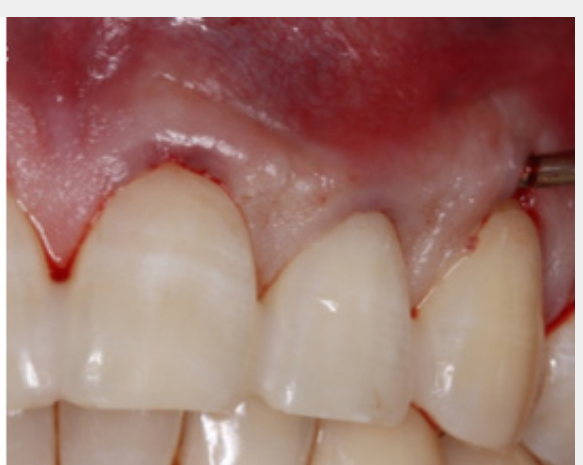

Figure 3: Elevation of gingivo-papillaer complex.

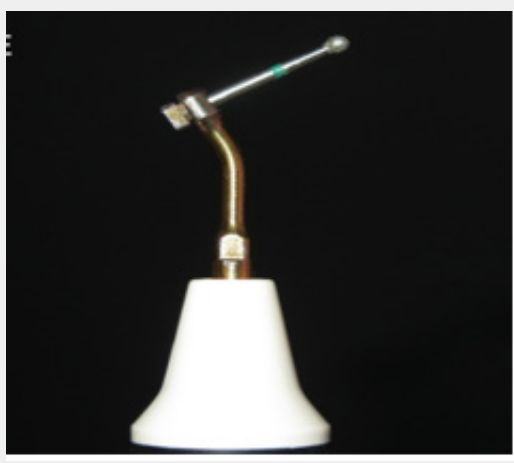

Figure 4: Special E-9 adaptor of round burr for ultrasonic scaler.

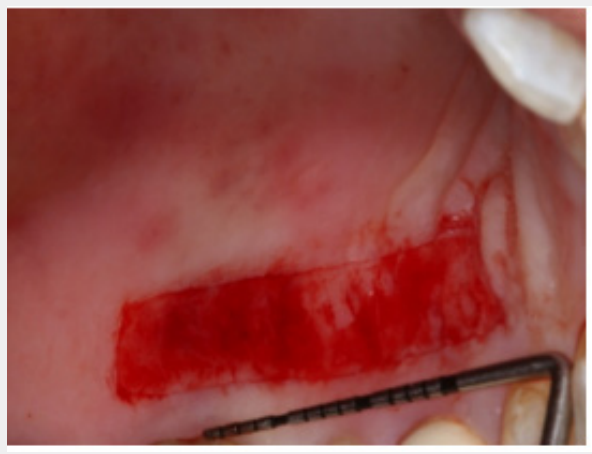

Figure 5: De-epithelialization of graft region intraorally.

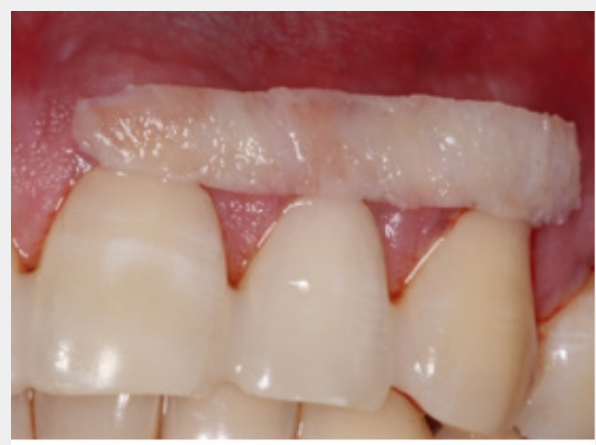

Figure 6: Harvested DGG. 


\section{Advances in Dentistry \& Oral Health}

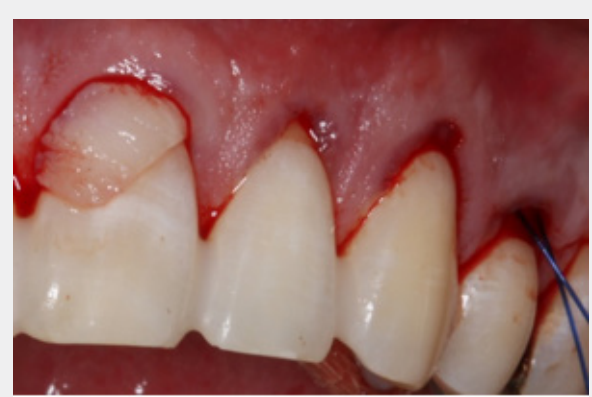

Figure 7: DGG introduced into tunnel bed.

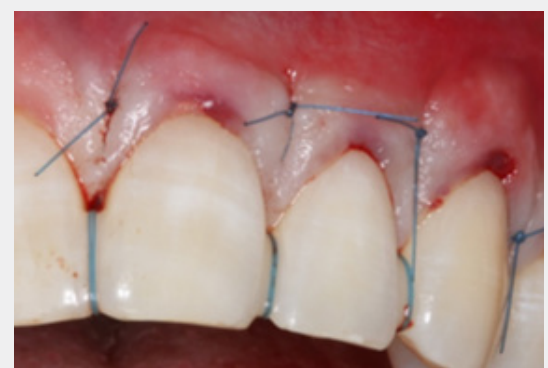

Figure 8: Vertical double-crossed sutures.

\section{Results}

Healing was uneventful. During healing time, there is no sign of necrosis on the recipient and donor area (Figure 9). Patient did not report pain, hemorrhage or discomfort. After 1 years of followup (Figure 10), the mean coverage was $92.2 \%$. Besides, increased gingival tissue thickness was observed.

Figure 9: 10 days after surgery.
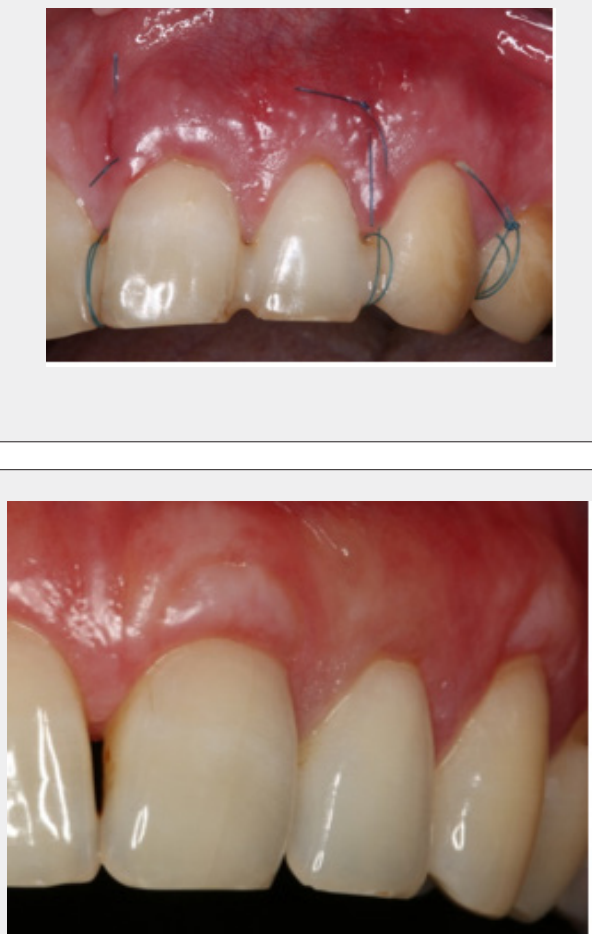

Figure 10: 12-month follow-up of the case. 


\section{Advances in Dentistry \& Oral Health}

\section{Discussion}

In the present article, a clinical case was reported in which the DGG was used with the tunnel technique to treat multiple GRs. Main of the difficulties ( anatomic limitations, graft size, graft thickness and graft shrinkage) have been recorded in complete root coverage of treatment of multiple GRs. Bertl et al. [29] showed that, DGG includes excessively dense collagen and low amounts of glandular/adipose tissue compared to CTG, as a result of histomorphometric analysis. Due to, graft minimum graft shrinkage has been reported [30]. Azar et al. [31] reported that, DGG could be considered as "dense CTG", included minimum adipose and epithelial tissue. Despite epithelial remnant cells during de-epithelialization [32], DGG was unique graft for root coverage [18].

\section{Conclusion}

The present case report reveals that DGG with tunnel technique is a successful treatment alternative for root coverage procedures of multiple adjacent gingival recession defects. This procedure has potential to increase soft tissue thickness, keratinized tissue gains and as well as to improve the final aesthetic outcomes. Postoperative healing was uneventful. Moreover, after a 1-year followup, the results were stable. In conclusion, DGG in combination with tunnel technique appears to be a good treatment option for treatment of multiple GRs.

\section{References}

1. Jepsen S, Jack G Caton, Jasim M Albandar, Nabil F Bissada, Philippe Bouchard, et al. (2018) Periodontal manifestations of systemic diseases and developmental and acquired conditions: Consensus report of workgroup 3 of the 2017 World Workshop on the Classification of Periodontal and Peri-Implant Diseases and Conditions. J Periodontol 89(Suppl 1): S237-s248.

2. Cairo F (2017) Periodontal plastic surgery of gingival recessions at single and multiple teeth. Periodontology 2000 75(1): 296-316.

3. Chambrone L, Luiz A Lima, Francisco E Pustiglioni, Luiz Armando Chambrone (2009) Systematic review of periodontal plastic surgery in the treatment of multiple recession-type defects. J Can Dent Assoc 75(3): 203a-203f.

4. Grupe HE, Warren RF (1956) Repair of Gingival Defects by a Sliding Flap Operation. The Journal of Periodontology 27(2): 92-95.

5. Cohen DW, Ross SE (1968) The double papillae repositioned flap in periodontal therapy. J Periodontol 39(2): 65-70.

6. Pennel BM, James D Higgason, Justin D Towner, Kenneth 0 King, Bobby D Fritz, et al. (1965) Oblique Rotated Flap. J Periodontol 36(4): 305309

7. Bernimoulin JP, Luscher B, Muhlemann HR (1975) Coronally repositioned periodontal flap. Clinical evaluation after one year. J Clin Periodontol 2(1): 1-13.

8. Tarnow DP (1986) Semilunar coronally repositioned flap. J Clin Periodontol 13(3): 182-185.

9. Miller PD (1982) Root coverage using a free soft tissue autograft following citric acid application. Part 1: Technique. Int J Periodontics Restorative Dent 2(1): 65-70.
10. Langer B, Langer L (1958) Subepithelial connective tissue graft technique for root coverage. J Periodontol 56(12): 715-20.

11. Nelson SW (1987) The subpedicle connective tissue graft. A bilaminar reconstructive procedure for the coverage of denuded root surfaces. J Periodontol 58(2): 95-102.

12. Raetzke PB (1985) Covering localized areas of root exposure employing the "envelope" technique. J Periodontol 56(7): 397-402.

13. Allen AL (1994) Use of the supraperiosteal envelope in soft tissue grafting for root coverage. I. Rationale and technique. Int J Periodontics Restorative Dent 14(3): 216-27.

14. Hammarstrom L (1997) Enamel matrix, cementum development and regeneration. J Clin Periodontol 24(9Pt2): 658-668.

15. Novaes AB (2001) Comparative 6-month clinical study of a subepithelial connective tissue graft and acellular dermal matrix graft for the treatment of gingival recession. J Periodontol 72(11): 1477-1484.

16. Pini Prato G (1992) Guided tissue regeneration versus mucogingival surgery in the treatment of human buccal gingival recession. J Periodontol 63(11): 919-928.

17. Zucchelli G (2010) Patient morbidity and root coverage outcome after subepithelial connective tissue and de-epithelialized grafts: a comparative randomized-controlled clinical trial. J Clin Periodontol 37(8): 728-738.

18. Bakhishov H (2021) De-epithelialized gingival graftversus subepithelial connective tissue graft in the treatment of multiple adjacent gingival recessions using the tunnel technique: 1 -year results of a randomized clinical trial. J Clin Periodontol.

19. Cieslik-Wegemund M (2016) Tunnel Technique with Collagen Matrix Compared with Connective Tissue Graft for Treatment of Periodontal Recession: A Randomized Clinical Trial. J Periodontol 87(12): 14361443.

20. Mahn DH (2010) Use of the tunnel technique and an acellular dermal matrix in the treatment of multiple adjacent teeth with gingival recession in the esthetic zone. Int J Periodontics Restorative Dent 30(6): 593-599.

21. McLeod DE, Reyes E, Branch Mays G (2009) Treatment of multiple areas of gingival recession using a simple harvesting technique for autogenous connective tissue graft. J Periodontol 80(10): 1680-1687.

22. Edel A (1974) Clinical evaluation of free connective tissue grafts used to increase the width of keratinised gingiva. J Clin Periodontol 1(4): 185-196.

23. Liu CL, Weisgold AS (2002) Connective tissue graft: a classification for incision design from the palatal site and clinical case reports. Int $J$ Periodontics Restorative Dent 22(4): 373-379.

24. Tavelli L (2019) What Is the Safety Zone for Palatal Soft Tissue Graft Harvesting Based on the Locations of the Greater Palatine Artery and Foramen? A Systematic Review. J Oral Maxillofac Surg 77(2): 271.e1271.e9.

25.Zucchelli (2013) Mucogingival Esthetic Surgery Technique for harvesting connective tisuue grafts. Italy: Quintessence.

26. Zuhr O (2009) A modified suture technique for plastic periodontal and implant surgery--the double-crossed suture. Eur J Esthet Dent 4(4): 338-347.

27. O Leary TJ, Drake RB, Naylor JE (1972) The plaque control record. J Periodontol 43(1): 38.

28. Loe H (1967) The Gingival Index, the Plaque Index and the Retention Index Systems. J Periodontol 38(6): 610-616. 
29. Bertl K (2015) Relative Composition of Fibrous Connective and Fatty/Glandular Tissue in Connective Tissue Grafts Depends on the Harvesting Technique but not the Donor Site of the Hard Palate. J Periodontol 86(12): 1331-1339.

30. Mele M (2008) Bilaminar technique in the treatment of a deep cervical abrasion defect. Int J Periodontics Restorative Dent 28(1): 63-71.
31. Azar EL (2019) Histologic and Histomorphometric Analyses of De-epithelialized Free Gingival Graft in Humans. Int J Periodontics Restorative Dent 39(2): 221-226.

32. Pall E (2017) New insights into the cellular makeup and progenitor potential of palatal connective tissues. Microsc Res Tech 80(12): 12701282.

\section{Your next submission with Juniper Publishers will reach you the below assets}

- Quality Editorial service

- Swift Peer Review

- Reprints availability

- E-prints Service

- Manuscript Podcast for convenient understanding

- Global attainment for your research

- Manuscript accessibility in different formats

( Pdf, E-pub, Full Text, Audio)

- Unceasing customer service

Track the below URL for one-step submission https://juniperpublishers.com/online-submission.php 